\title{
Influence of Monochromatic Light on the Action of Enzymes.
}

\author{
Especially Influence of Monochromatic Light on the \\ Action of Yeast Enzymes. \\ By Reitaro Murakami. \\ (Chemical Laboratory, Agricultural College, Utunomiya.) \\ Received March 6, 1940.
}

In order to study the effects of spectral monochromatic light on the action of yeast enzymes, saccharase, proteinase, catalase, amylase, and lipase were extracted by autolyzing "Oriental" pressed yeast, the first three of which were refined as follows. In the case of saccharase, after the liquefaction was completed by the addition of $10 \%$ of toluene to $225 \mathrm{~g}$ of the yeast, the same volume of water was added and the whole allowed to autolyze at room temperature for 7 days. The precipitate obtained by adding an equal volume of alcohol to the autolyzed liquid was extracted with $20 \%$ alcohol. Alcohol was then added to the extract, and the saccharase extracted from the second precipitate with $100 \mathrm{cc}$ of water.

In the case of proteinase, after $250 \mathrm{~g}$ of the yeast was liquefied by the addition of $10 \%$ of ethyl acetate, $500 \mathrm{cc}$ of water was added and the acid that had formed in 2 hours was neutralized continuously by the addition of ammonia water and then a solution that rendered ineffective the tryptic and ereptic actions was separated out and washed with water. The yeast was then suspended in water containing toluene and allowed to autolyze at room temperature for 24 hours. An acetic solution was added to the autolyzate obtained by filtration, and after the $\mathrm{pH}$ of the liquid was made 5.0, a $N / 15$ acetate buffer of $\mathrm{pH} 5.0$ and aluminium hydroxide were added. The proteinase was finally obtained by elution of the adsorbate with $44 \mathrm{cc}$ of secondary ammonium phosphate.

Catalase was prepared by liquefying yeast. By adding to $150 \mathrm{~g}$ of it $33 \%$ of toluene the yeast was liquefied within 1 hour at $40^{\circ} \mathrm{C}$, after which $200 \mathrm{cc}$ of water was added, and the whole allowed to autolyze overnight in a refrigerator. To the autolyzate was added $44 \mathrm{cc}$ of $N / 10$ hydrochloric acid, and the total volume of liquid made up to $2000 \mathrm{cc}$ with water to which aluminium hydroxide was finally added. The catalase was obtained by elution of the adsorbate with $400 \mathrm{cc}$ of $M / 30$ phosphate solution ( $\mathrm{pH}=7.6$ ).

Amylase and lipase were prepared by autolyzing for 1 day at room temperature and then overnight in a refrigerator after adding $10 \%$ of toluene and 2.5 times the volume of water to $200 \mathrm{~g}$ of the yeast.

As substrate for the saccharase, 20\% saccharose dissolved in $1 \%$ primary sodium phosphate solution was used. Into a test tube containing $4 \mathrm{cc}$ of the substrate, $1 \mathrm{cc}$ of the enzyme solution was added, and the $\mathrm{pH}$ of the resulting solution 
[Vol. 16,

adjusted to 4.24. The substrate for the amylase was $1 \%$ soluble starch solution. Into a test tube containing $10 \mathrm{cc}$ each of the substrate and phosphate buffer solution, $10 \mathrm{cc}$ of the enzyme solution was added, and the $\mathrm{pH}$ of the solution adjusted to 6.71. The substrate for the proteinase was $5 \%$ gelatine solution. Into a test tube containing $5 \mathrm{cc}$ each of the substrate and citrate buffer, $1 \mathrm{cc}$ of the enzyme solution was added, the resulting $\mathrm{pH}$ of the solution being 5.1. The substrate for the lipase, which was castor oil or olive oil, was neutralized with $N / 20$ sodium hydroxide. Into a test tube containing $5 \mathrm{cc}$ of the substrate, $5 \mathrm{cc}$ of the enzyme solution was added, and the $\mathrm{pH}$ of the resulting solution adjusted to 7.4. The substrate for catalase was $N / 20$ hydrogen peroxide buffered with phosphate mixture, the $\mathrm{pH}$ of which was 6.7. One $\mathrm{cc}$ of the enzyme solution was added to a test tube containing $20 \mathrm{cc}$ of the substrate. The test tubes were placed within tin boxes, and filters placed at the front windows of the boxes. The boxes containing the test tubes were incubated at from $20^{\circ}$ to $40^{\circ} \mathrm{C}$, according to the particular enzyme, the door opened, and then lighted by a lamp through filters and a $2 \mathrm{~cm}$ layer of $N / 10$ copper sulphate solution (except in the case of work on infra-red rays), as the copper solution absorbs infra-red rays from a distance of 1 meter.

As the light source, a nitra lamp (Mazda C 100 300 watt and O. K. 500 watt) was used for visible rays. "Vim Ray" blue and red lamps (each 300 watt) used respectively for ultra-violet and infra-red rays.

The filters were made by spreading $7 \mathrm{cc}$ of gelatine solutions, containing various pigments per 1 square dm, over colourless glass or "Acme ultra vit glass" plates which were used respectively for the purpose of visible and infra-red rays or ultra-violet rays, and then drying by means of a fan. The amounts of pigment per $70 \mathrm{cc}$ of gelatine solution are shown in Table $\mathrm{I}$.

Table I. Composition of the filters.

\begin{tabular}{|c|c|c|}
\hline Plate & Filter & Pigment \\
\hline $\begin{array}{c}\text { "Acme ultra } \\
\text { vit glass" } \\
\text { plate }\end{array}$ & $\begin{array}{l}\text { White filter } \\
\text { Infra-red pass filter } \\
\text { Red filter } \\
\text { Green filter } \\
\text { Blue filter } \\
\text { Violet filter } \\
\text { Black filter } \\
\text { Ultra-violet close filter } \\
\text { Ultra-violet pass filter }\end{array}$ & $\begin{array}{l}\text { Aesculin } 0.2 \mathrm{~g} \text { or gelatine alone } \\
\text { Filter blue } 0.1+\text { filter yellow } 0.1+\text { toluidine blue } \\
0.01 \mathrm{~g} \\
\text { Rhodamine } 0.42+\text { tartrazine } 0.42+\text { erythrosine } \\
\quad 0.42 \mathrm{~g} \\
\text { Patent blue } 0.2+\text { tartrazine } 0.7 \mathrm{~g} \\
\text { Patent blue } 0.2+\text { rhodamine } 0.7+\text { aesculin } 0.2 \mathrm{~g} \\
\text { Methyl violet } 0.42+\text { toluidine blue } 0.17+\text { aes- } \\
\text { culin } 0.2 \mathrm{~g} \\
\text { India ink } 3.5 \mathrm{cc} \\
\text { Aesculin } 0.2 \mathrm{~g} \\
\text { Nitrosodimethylaniline } 0.03+\text { toluidine blue } \\
\quad 0.06+\text { copper sulphate } 0.874 \mathrm{~g}\end{array}$ \\
\hline
\end{tabular}

As to the wave lengths of the transmission rays passed through these filters, they were spectroscopically examined; the photograms, which were taken by means of a constant deviation wave length spectrometer and a quartz spectrograph, are 

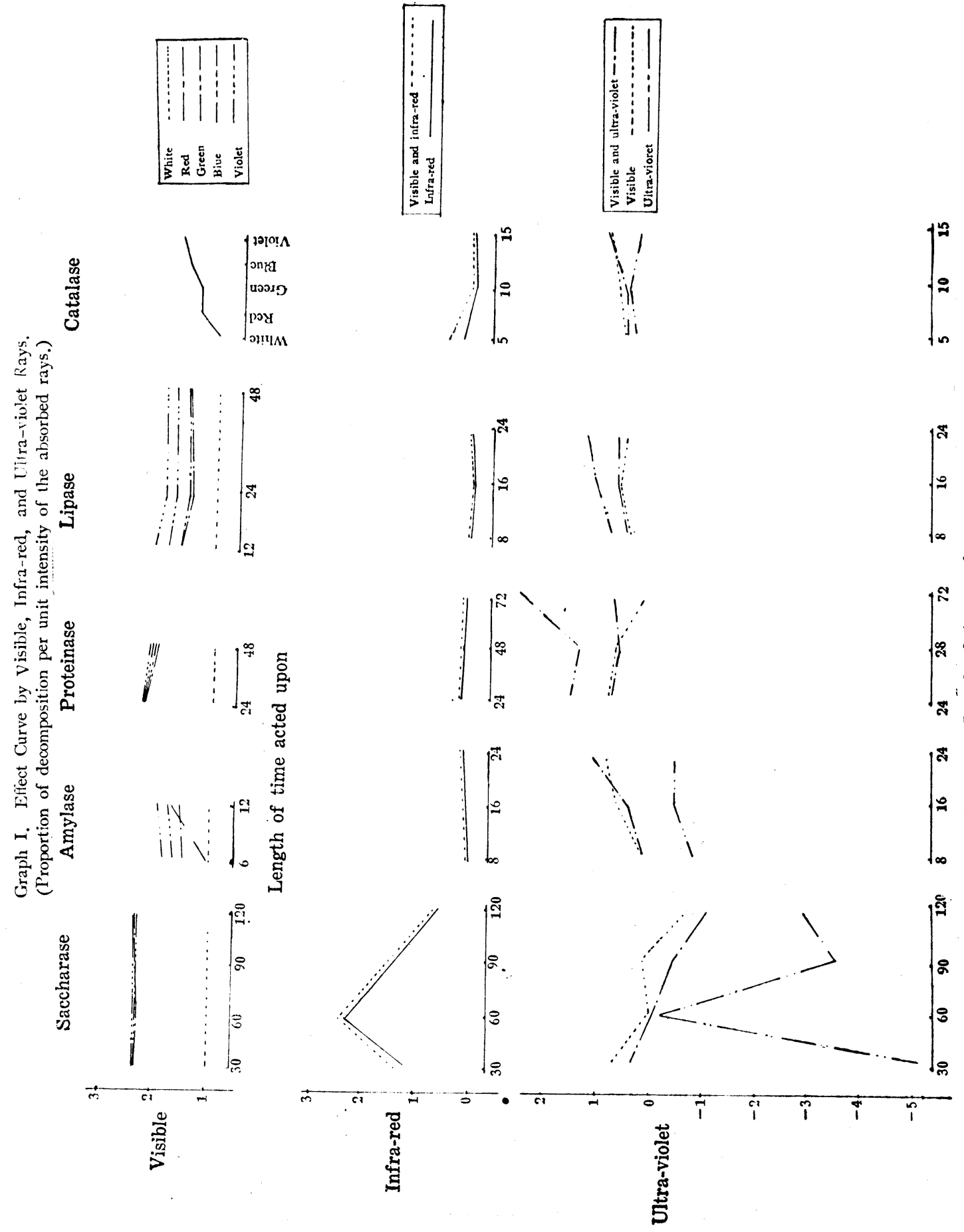

uo!̣jodoxd 
Graph II (1) Effect Curve by Like and Various Coloured Lights.

(Proportion of decomposition per unit intensity of the absorbed rays).

Saccharase

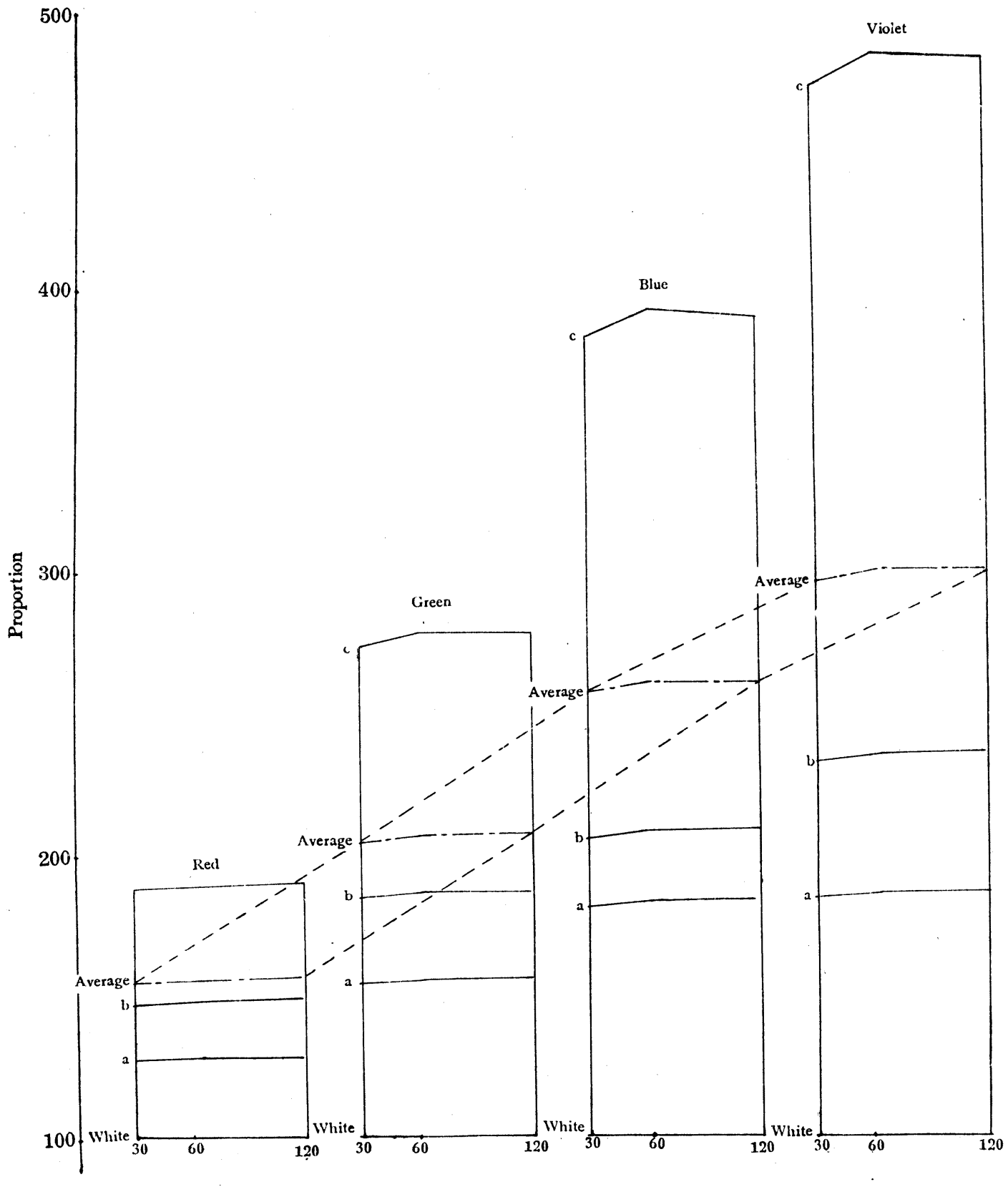

Length of time acted upon 


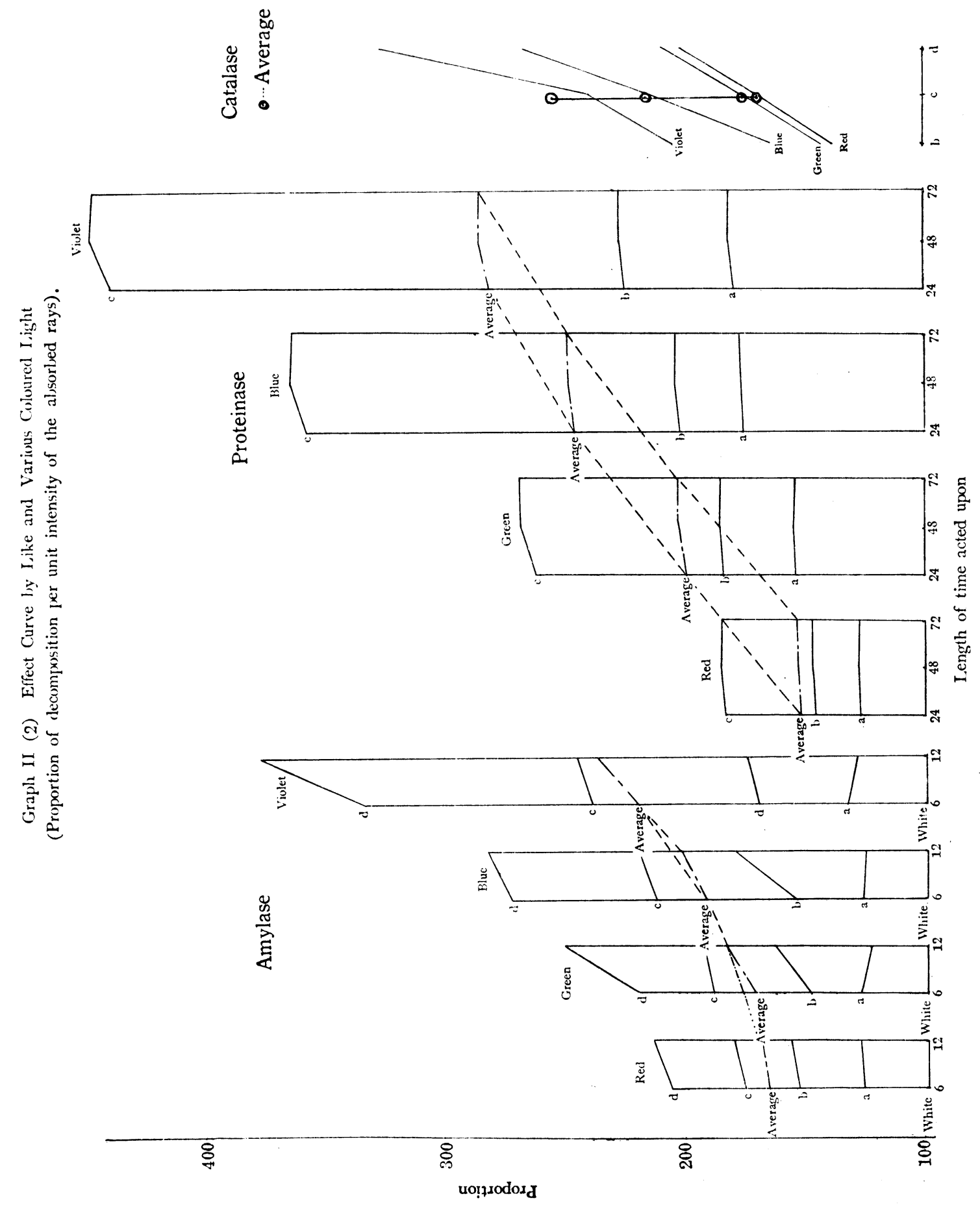


shown in Plates $\mathrm{I} \sim \mathrm{V}$. The relative intensities of the transmission rays and the rays absorbed in the substrates or the enzyme solutions containing the substrates were measured by means of a sensitive galvanometer and a vacuum thermojunction, the junction part of which was blackened by carbon, and the determination made in comparison with a Mazda C 100 watt lamp as standard. The intensity per $\mathrm{cm}^{2} / \mathrm{sec}$. of a Mazda C 100 watt lamp compared with a Hefner lamp, candle power of which was corrected for temperature, humidity, and atmospheric pressure in the room corresponded to 12.525 , and the intensities of the transmission rays of the former passing through the white filter, and the white filter plus a $2 \mathrm{~cm}$ layer of $N / 10$ copper sulphate, corresponded respectively to 8.017 and 0.422 . The total energy per $\mathrm{cm}^{2} / \mathrm{sec}$. of the incident light from the Hefner lamp at a distance of 1 meter was $215 \times 10^{-7}$ gram calory as determined by Ångstrom. The details are given in the following Table.

Table II. Wave lengths and relative intensities.

\begin{tabular}{|c|c|c|c|c|c|c|c|c|}
\hline & \multirow[t]{2}{*}{ Filter } & \multirow{2}{*}{$\begin{array}{l}\text { Transmission } \\
\text { wave length } \\
\text { (I. §.) } \\
\text { Light source } \\
\text {-Lamp. }\end{array}$} & \multirow{2}{*}{$\begin{array}{l}\text { Relative } \\
\text { intensity of } \\
\text { transmission } \\
\text { rays }\end{array}$} & \multicolumn{5}{|c|}{$\begin{array}{l}\text { Relative intensity of the rays absorbed in the } \\
\text { substrate or in the enzyme solution containing } \\
\text { the substrate }\end{array}$} \\
\hline & & & & Saccharase & Amylase & Proteinase & Lipase & Catalase \\
\hline \multirow{3}{*}{ 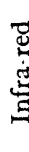 } & White filter & $5,700 \sim 30,000$ & 2.08 & 2.18 & 2.11 & 2.09 & 2.08 & 2.08 \\
\hline & $\begin{array}{l}\text { Infra-red } \\
\text { pass filter }\end{array}$ & $8,000 \sim 30,000$ & 2.04 & 2.13 & 2.06 & 2.03 & 2.04 & 2.05 \\
\hline & (Black filter & None & 0 & 0 & 0 & 0 & 0 & 0 \\
\hline \multirow{5}{*}{ 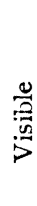 } & White filter & $4,000 \sim 8,000$ & 1.00 & 1.00 & 1.00 & 1.00 & 1.00 & 1.00 \\
\hline & Red filter & $6,200 \sim 8,000$ & 0.67 & 0.42 & 0.63 & 0.46 & 0.67 & 0.71 \\
\hline & Green filter & $5,170 \sim 5,400$ & 0.63 & 0.42 & 0.60 & 0.46 & 0.63 & 0.69 \\
\hline & Blue filter & $4,300 \sim 4,800$ & 0.55 & 042 & 0.54 & 0.46 & 0.55 & 0.61 \\
\hline & Violet filter & $4,100 \sim 4,470$ & 0.48 & 0.42 & 0.48 & 0.46 & 0.48 & 0.55 \\
\hline \multirow{5}{*}{ 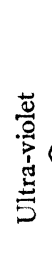 } & Black filter & None & 0 & $\mathbf{0}$ & 0 & 0 & 0 & 0 \\
\hline & (White filter & $3,500 \sim 5,500$ & 0.33 & 0.43 & 0.32 & 0.40 & 0.27 & 0.35 \\
\hline & $\begin{array}{l}\text { Ultra-violet } \\
\text { close filter }\end{array}$ & $4,100 \sim 5,500$ & 0.32 & 0.40 & 0.32 & 0.37 & 0.27 & 0.35 \\
\hline & $\begin{array}{l}\text { Ultra-violet } \\
\text { pass filter }\end{array}$ & $3,500 \sim 4,000$ & 0.15 & 0.17 & 0.18 & 0.17 & 0.10 & 0.20 \\
\hline & Black filter & None & 0 & 0 & 0 & 0 & 0 & $\mathbf{0}$ \\
\hline
\end{tabular}

The test tubes were removed from each box at fixed internavals after the incubation and the end products of the action of the enzymes were determined by Bertrand's method for saccharase and amylase, by the formol method for proteinase, by Knitz's method for lipase, and by the permanganate titration method for catalase.

The controls were deducted from the quantitative values. The differences correspond to the real amounts of the substrates decomposed by the action of the emzymes. In the case of visible rays, the index-numbers obtained from the real amounts under each of the various lights other than white, compared with white light as a standard, were divided by the relative intensities of the absorbed rays. 
In the case of infra-red and ultra-violet rays, the differences between the black and other rays were divided by the relative intensities of the absorbed rays. Thus, the extent of decomposition caused by the enzymes per unit intensity of the absorbed rays were obtained in both cases. The extent of action of the enzymes under the influence of different lights was compared with the proportions of the quotients that were obtained as already mentioned (See Table V).

The results with the controls deducted from the quantitative values are shown in Table III.

The percentages of the substrates decomposed by the enzymes are given in Table IV.

The extent of decomposition of the substrates by the enzymes, that is to say, the proportions of the quotients per unit intensity of the absorbed rays, are given in Table $\mathrm{V}$.

In this experiment, the actions of saccharase, amylase, proteinase, lipase, and catalase were affected only very slightly by the infra-red. rays. This applies to the first-named; the others were scarcely affected by the infra-red rays. The enzymes were more active under rays containing both visible and infra-red. Promotion of enzyme action by visible rays was found to be more pronounced under rays of shorter rather than longer wave length, gradually weakening with increase in wave length. The actions of saccharase, amylase, and catalase were found to be inhibited, contrary to the actions of proteinase and lipase, which were promoted by the near ultra-violet vays. The action of these enzymes irradiated previously by the near ultra-violet or infra-red rays was closely in agreement with the above result. It is therefore believed that the limits to the actions of saccharase, amylase, and catalase lie near the ultra-violet region, close to the violet, that is to say, the actions of these enzymes were promoted or inhited under wave lengths either longer or shorter than that from a certain point in the near ultra-violet region. In the cases of proteinase and lipase, seeing that the activities of the two enzymes were found to increase more with near ultra-violet rays than with the visible rays, it cannot be said that their activities had reached their limits.

The writer made further investigations into the effect of visible rays on the action of these enzymes, using series of like and different coloured lights consisting of red, green, blue, and violet, each in three or four different wave lengths and intensities. The light source and the means of eliminating the infrared and ultraviolet rays were the same as already described. The transmission wave lengths through the filters and the relative intensities of the absorbed rays in the substrates or the enzyme solutions containing the substrates are given in Table VI. See also plates VI, VII.

The other methods used, except those of the filters held at the front of the boxes were also the same as those already described.

The results, with the controls deducted from the quantitative values are shown in Table VII.

The percentages of the substrates decomposed by the enzymes are given in a Table VIII. 


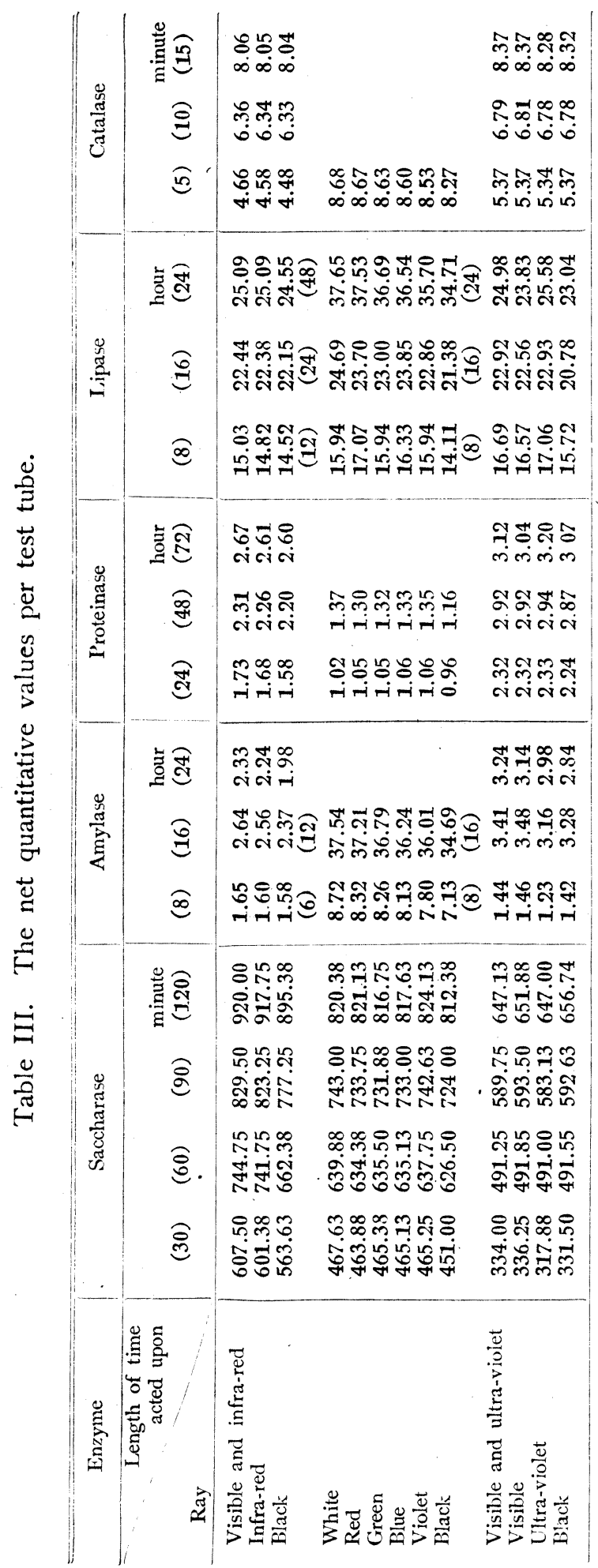

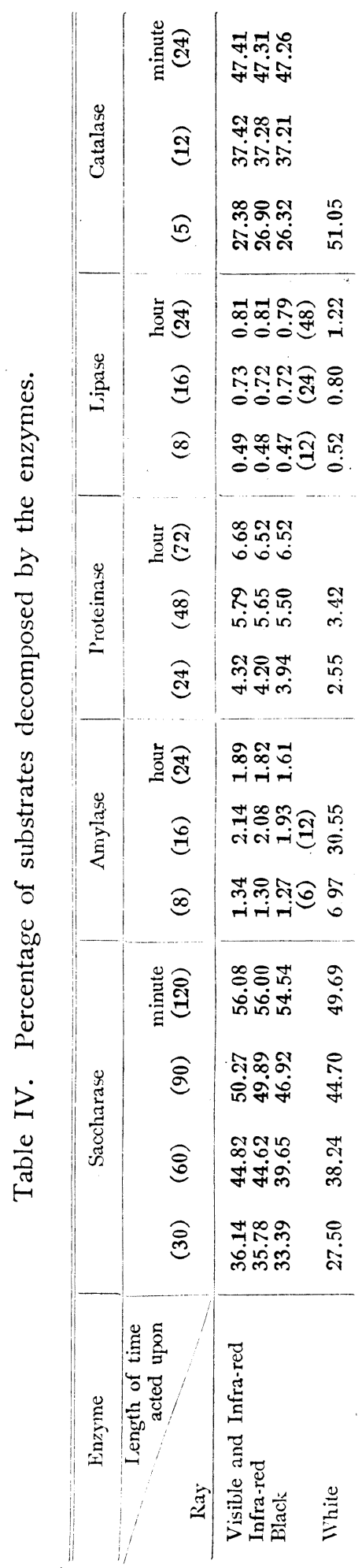




\begin{tabular}{|c|c|}
\hline & 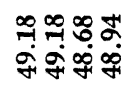 \\
\hline & 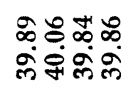 \\
\hline 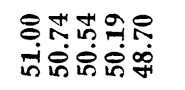 & 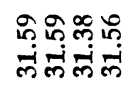 \\
\hline 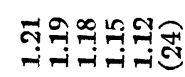 & 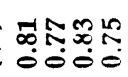 \\
\hline 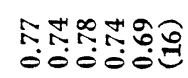 & 勇息 \\
\hline 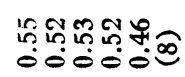 & 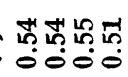 \\
\hline & 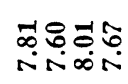 \\
\hline 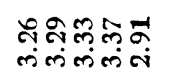 & 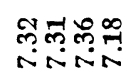 \\
\hline 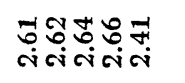 & 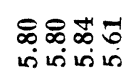 \\
\hline & 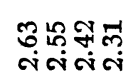 \\
\hline 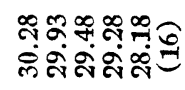 & 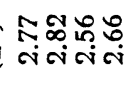 \\
\hline 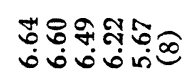 & 욱: \\
\hline 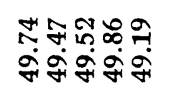 & 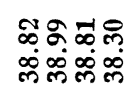 \\
\hline 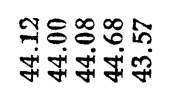 & 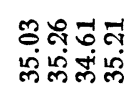 \\
\hline  & 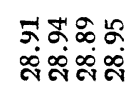 \\
\hline 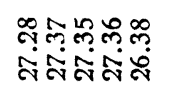 & 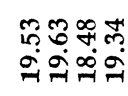 \\
\hline 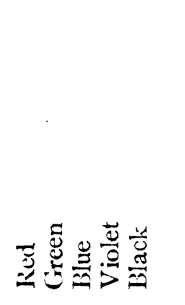 & 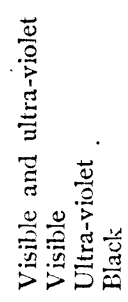 \\
\hline
\end{tabular}

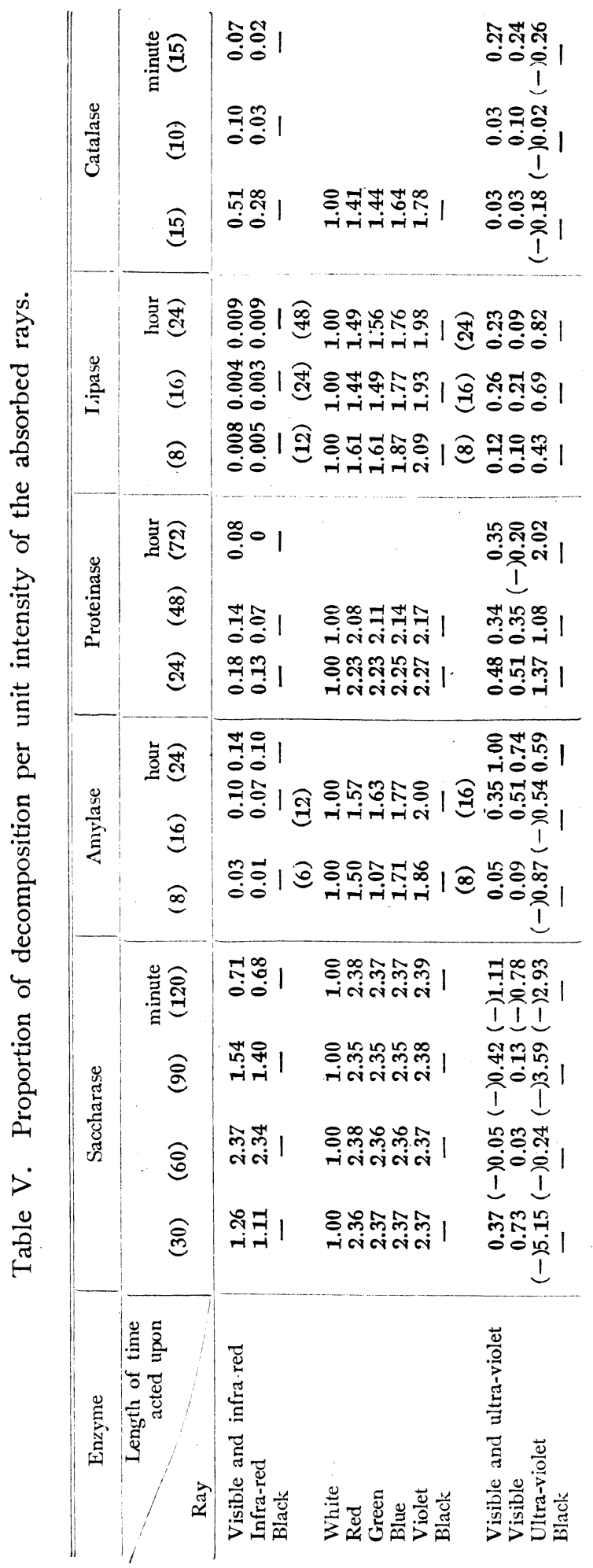


Table VI. The wave lengths and the relative intensities.

\begin{tabular}{|c|c|c|c|c|c|c|}
\hline \multirow{2}{*}{\multicolumn{2}{|c|}{ Filter }} & \multirow{2}{*}{$\begin{array}{l}\text { Transmission wave } \\
\text { length (I. Å.) } \\
\text { Light source-Lamp. }\end{array}$} & \multicolumn{4}{|c|}{ Relative intensities of the absorbed rays } \\
\hline & & & Saccharase & Amylase & Proteinase & Catalase \\
\hline \multicolumn{2}{|l|}{ White } & $4,000 \sim 8,000$ & 1.00 & 1.00 & 1.00 & 1.00 \\
\hline \multirow[t]{4}{*}{ Red } & a & $6,000 \sim 8,000$ & 0.78 & 0.78 & 0.79 & - \\
\hline & $\mathrm{b}$ & $6,050 \sim 8,000$ & 0.67 & 0.63 & 0.68 & 0.71 \\
\hline & $\mathrm{c}$ & $6,130 \sim 8,000$ & 0.52 & 0.52 & 0.54 & 0.59 \\
\hline & $\mathrm{d}$ & $6,230 \sim 8,000$ & - & 0.42 & - & 0.49 \\
\hline \multirow[t]{4}{*}{ Green } & $\mathbf{a}$ & $5,000 \sim 5,700$ & 0.63 & 0.76 & 0.64 & - \\
\hline & $\mathrm{b}$ & $5,140 \sim 5,500$ & 0.53 & 0.60 & 0.53 & 0.69 \\
\hline & $\mathrm{c}$ & $5,170 \sim 5,400$ & 0.35 & 0.48 & 0.37 & 0.56 \\
\hline & d & $5,200 \sim 5,400$ & - & 0.38 & - & 0.46 \\
\hline \multirow[t]{4}{*}{ Blue } & $\mathrm{a}$ & $4,200 \sim 4,960$ & 0.54 & 0.74 & 0.56 & - \\
\hline & $\mathrm{b}$ & $4,270 \sim 4,900$ & 0.47 & 0.54 & 0.49 & 0.61 \\
\hline & $\mathrm{c}$ & $4,300 \sim 4,800$ & 0.25 & 0.40 & 0.27 & 0.46 \\
\hline & d & $4,380 \sim 4,700$ & - & 0.30 & - & 0.35 \\
\hline \multirow[t]{4}{*}{ Violet } & $\mathrm{a}$ & $4,000 \sim 4,530$ & 0.53 & 0.69 & 0.54 & - \\
\hline & $\mathrm{b}$ & $4,100 \sim 4,470$ & 0.42 & 0.48 & 0.43 & 0.55 \\
\hline & $\mathrm{c}$ & $4,150 \sim 4,400$ & 0.20 & 0.33 & 0.22 & 0.40 \\
\hline & $d$ & $4,150 \sim 4,300$ & - & 0.23 & - & 0.28 \\
\hline Black & & None & 0 & 0 & 0 & 0 \\
\hline
\end{tabular}

Table VII. The net quantitative values per test tube.

Remark: At amylase, one series marked $\Delta$ and other series unmarked.

\begin{tabular}{|c|c|c|c|c|c|c|c|c|c|c|}
\hline \multicolumn{2}{|c|}{ Enzyme } & \multicolumn{3}{|c|}{ Saccharase } & \multicolumn{2}{|c|}{ Amylase } & \multicolumn{3}{|c|}{ Proteinase } & Catalase \\
\hline \multicolumn{2}{|c|}{$\begin{array}{r}\text { I.ength of time } \\
\text { acted upon }\end{array}$} & \multicolumn{3}{|c|}{$\begin{array}{l}\mathrm{mg} \text { of } \\
\text { reduced } \\
\text { copper }\end{array}$} & \multicolumn{2}{|c|}{$\begin{array}{l}\text { mg of } \\
\text { reduced } \\
\text { copper }\end{array}$} & \multicolumn{3}{|c|}{$\begin{array}{c}\mathrm{mg} \text { of } \\
\text { nitrogen } \\
\text { decomposed }\end{array}$} & $\begin{array}{c}\mathrm{mg} \text { of } \\
\mathrm{H}_{2} \mathrm{O}_{2} \\
\text { decomposed }\end{array}$ \\
\hline Ray & & 30 & 60 & $\begin{array}{c}\text { minute } \\
120\end{array}$ & 6 & $\begin{array}{c}\text { hour } \\
12\end{array}$ & 24 & 48 & $\begin{array}{c}\text { hour } \\
72\end{array}$ & $\begin{array}{c}\text { minute } \\
\mathbf{1 5}\end{array}$ \\
\hline \multicolumn{2}{|l|}{ White } & 552.50 & 746.38 & 871.88 & $\begin{array}{l}35.88^{\triangle} \\
12.47\end{array}$ & $\begin{array}{l}44.48^{\triangle} \\
56.78\end{array}$ & 3.60 & 4.93 & 6.26 & 8.89 \\
\hline \multirow[t]{4}{*}{ Red } & a & 547.50 & 742.88 & 874.75 & $35.25 \triangle$ & $44.18^{\triangle}$ & 3.59 & 4.92 & 6.24 & - \\
\hline & b & 543.75 & 739.50 & 870.00 & 12.16 & 56.39 & 3.56 & 4.90 & 6.21 & 8.89 \\
\hline & c & 540.25 & 725.38 & 864.13 & $32.82 \triangle$ & $41.47^{\triangle}$ & 3.53 & 4.88 & 6.21 & 8.79 \\
\hline & d & - & - & - & 10.75 & 54.09 & - & - & - & 8.69 \\
\hline \multirow[t]{4}{*}{ Green } & a & 543.13 & 738.75 & 868.63 & $34.66^{\triangle}$ & $41.70^{\triangle}$ & 3.56 & 4.89 & 6.21 & - \\
\hline & b & 540.50 & 736.00 & 864.25 & 11.22 & 54.98 & 3.53 & 4.88 & 6.21 & 8.79 \\
\hline & c & 533.50 & 732.25 & 856.88 & $32.11^{\triangle}$ & $40.69 \triangle$ & 3.50 & 4.85 & 6.14 & $8.70^{\circ}$ \\
\hline & d & - & - & - & 10.19 & 53.48 & - & - & - & 8.61 \\
\hline \multirow[t]{4}{*}{ Blue } & a & 540.88 & 736.75 & 864.50 & $33.59 \triangle$ & $40.76^{\triangle}$ & 3.54 & 4.89 & 6.21 & - \\
\hline & b & 538.75 & 734.88 & 862.25 & 1037 & 54.50 & 3.53 & 4.87 & 6.19 & 8.75 \\
\hline & $\cdot c$ & 529.63 & 731.63 & 852.13 & $30.32^{\triangle}$ & $39.09 \wedge$ & 3.46 & 4.83 & 6.12 & 8.65 \\
\hline & d & - & - & - & 9.90 & 52.96 & - & - & - & 8.50 \\
\hline Violet & a & 540.75 & 736.25 & 864.38 & $32.80^{\triangle}$ & $39.49 \triangle$ & 3.53 & 4.88 & 6.20 & - \\
\hline
\end{tabular}




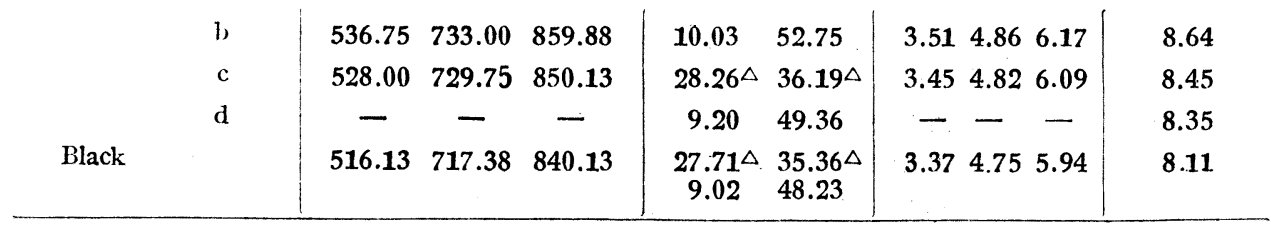

Table VIII. The percentages of substrates decomposed by the enzyme.

\begin{tabular}{|c|c|c|c|c|c|c|c|c|c|c|}
\hline \multicolumn{2}{|c|}{ Enzyme } & \multicolumn{3}{|c|}{ Saccharase } & \multicolumn{2}{|c|}{ Amylase } & \multicolumn{3}{|c|}{ Proteinase } & \multirow{2}{*}{$\begin{array}{c}\text { Catalase } \\
\text { minute } \\
15\end{array}$} \\
\hline Ler & $u_{1}$ & 30 & 60 & $\begin{array}{c}\text { minute } \\
120\end{array}$ & 6 & $\begin{array}{l}\text { hour } \\
12\end{array}$ & 24 & 48 & $\begin{array}{c}\text { hour } \\
72\end{array}$ & \\
\hline White & & 32.69 & 44.93 & 53.07 & $\begin{array}{l}29.15^{\triangle} \\
10.04\end{array}$ & $\begin{array}{l}36.32 \triangle \\
46.59\end{array}$ & 9.01 & 12.33 & 15.65 & 52.30 \\
\hline \multirow[t]{4}{*}{ Red } & $a$ & 32.38 & 44.69 & 53.24 & $28.39 \triangle$ & $36.06^{\triangle}$ & 8.97 & 12.32 & 15.60 & - \\
\hline & $b$ & 32.15 & 44.48 & 52.92 & 9.79 & 46.26 & 8.91 & 12.26 & 15.55 & 52.24 \\
\hline & c & 31.93 & 44.22 & 52.54 & $26.61^{\triangle}$ & $33.81^{\triangle}$ & 8.84 & 12.21 & 15.53 & 51.66 \\
\hline & $d$ & - & - & - & 8.63 & 44.34 & - & - & - & 51.09 \\
\hline \multirow[t]{4}{*}{ Green } & $a$ & 32.12 & 44.42 & 52.83 & $28.15^{\triangle}$ & $34.00^{\triangle} \triangle$ & 8.90 & 12.25 & 15.54 & - \\
\hline & b & 31.94 & 44.26 & 52.55 & 9.02 & 45.07 & 8.84 & 12.21 & 15.53 & 51.70 \\
\hline & $\mathrm{c}$ & 31.51 & 44.02 & 52.06 & $26.03^{\triangle}$ & $33.16^{\triangle}$ & 8.75 & .12 .13 & 15.38 & 51.18 \\
\hline & $d$ & - & - & - & 8.18 & 43.84 & - & - & - & 50.65 \\
\hline \multirow[t]{4}{*}{ Blue } & $a$ & 31.97 & 44.30 & 52.57 & $27.25^{\triangle}$ & $33.68^{\triangle}$ & 8.85 & 12.24 & 15.54 & - \\
\hline & $b$ & 31.83 & 44.18 & 52.42 & 8.32 & 44.68 & 8.83 & 12.19 & 15.48 & 51.48 \\
\hline & $\mathrm{c}$ & 31.27 & 43.98 & 51.75 & $24.57^{\triangle}$ & $31.84^{\triangle}$ & 8.67 & 12.08 & 15.31 & 50.89 \\
\hline & $d$ & - & - & - & 7.93 & 43.41 & - & - & $\vdots$ & 49.95 \\
\hline \multirow[t]{4}{*}{ Violet } & $a$ & 31.97 & 44.27 & 52.55 & $26.59 \triangle$ & $32.15^{\triangle}$ & 8.84 & 12.22 & 15.53 & - \\
\hline & b & 31.72 & 44.07 & 52.26 & 8.04 & 43.24 & 8.79 & 12.16 & 15.43 & 50.82 \\
\hline & $\mathrm{c}$ & 31.17 & 43.87 & 51.62 & $22.92^{\triangle}$ & $29.42^{\triangle}$ & 8.63 & 12.05 & 15.25 & 49.67 \\
\hline & $d$ & - & - & - & 7.36 & 40.47 & - & - & - & 48.97 \\
\hline Black & & 30.42 & 42.97 & 50.95 & $\begin{array}{c}22.47 \triangle \\
7.22\end{array}$ & $\begin{array}{l}28.70^{\triangle} \\
39.54\end{array}$ & 8.42 & 11.88 & 14.87 & 47.66 \\
\hline
\end{tabular}

The index-numbers for decomposition under each coloured light compared with that under white light as standard is shown in the following Table.

Table IX. The index-numbers for decomposition under each light.

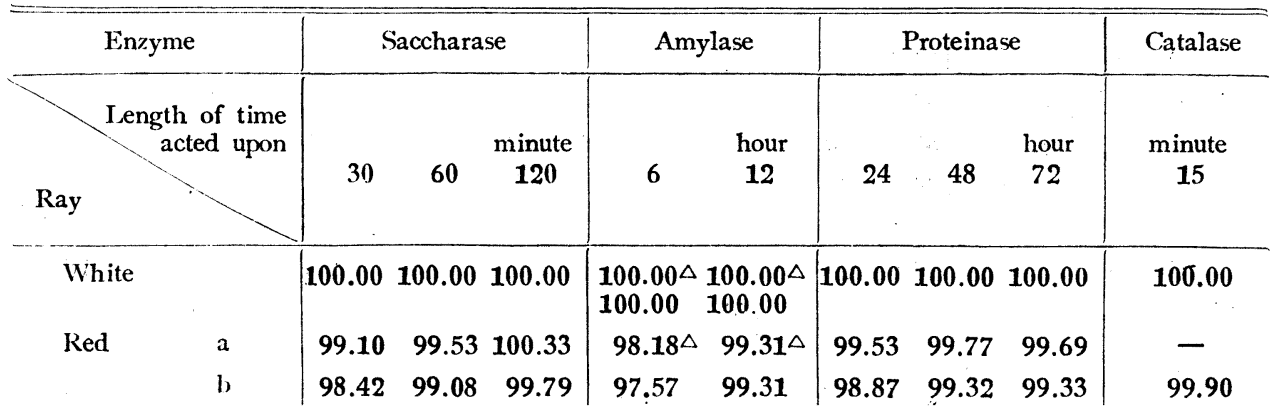




\begin{tabular}{|c|c|c|c|c|c|c|c|c|c|c|}
\hline & $\mathrm{c}$ & 97.78 & 98.53 & 99.11 & $91.75^{\triangle}$ & $93.27 \triangle$ & 98.06 & 98.95 & 99.22 & 98.88 \\
\hline & $d$ & - & - & - & 87.20 & 90.33 & - & - & - & 97.75 \\
\hline \multirow[t]{4}{*}{ Green } & $\mathrm{a}$ & 98.30 & 98.98 & 99.63 & $96.68^{\triangle}$ & $93.83 \triangle$ & 98.72 & 99.21 & 99.31 & - \\
\hline & $\mathrm{b}$ & 97.83 & 98.61 & 99.13 & 89.27 & 97.55 & 98.06 & 98.95 & 99.22 & 98.88 \\
\hline & $\mathrm{c}$ & 96.56 & 98.11 & 98.28 & $89.62 \triangle$ & $91.54 \triangle$ & 97.04 & 98.24 & 98.23 & 97.86 \\
\hline & $d$ & - & - & - & 82.45 & 94.32 & - & - & - & 96.85 \\
\hline \multirow[t]{4}{*}{ Blue } & $\mathrm{a}$ & 97.90 & 98.71 & 99.15 & $93.54 \triangle$ & $92.73 \triangle$ & 98.18 & 99.03 & 99.26 & - \\
\hline & $b$ & 97.51 & 98.46 & 98.90 & 84.12 & 96.87 & 97.94 & 98.75 & $98.93^{\circ}$ & 98.43 \\
\hline & $\mathrm{c}$ & 95.86 & 98.02 & 97.74 & $85.06^{\triangle}$ & $88.00^{\triangle}$ & 96.15 & 97.84 & 97.81. & 97.30 \\
\hline & $d$ & - & - & - & 80.56 & 9288 & - & - & - & 95.61 \\
\hline \multirow[t]{4}{*}{$V$ iolet } & $\mathrm{a}$ & 97.87 & 98.64 & 99.14 & $91.32 \triangle$ & $89.36 \triangle$ & 98.13 & 98.98 & 99.19 & - \\
\hline & $b$ & 97.15 & 98.21 & 9862 & 81.34 & 93.30 & 97.55 & 98.52 & 98.59 & 97.19 \\
\hline & $\mathrm{c}$ & 95.57 & 97.77 & 97.51 & $79.13^{\triangle}$ & $81.41^{\triangle}$ & 95.72 & 97.64 & 97.42 & 95.05 \\
\hline & $d$ & - & - & - & 76.08 & 85.96 & - & - & - & 93.93 \\
\hline Black & & 93.41 & 96.12 & 96.36 & $\begin{array}{l}77.58^{\triangle} \\
74.59\end{array}$ & $\begin{array}{l}79.54 \triangle \\
83.98\end{array}$ & 93.43 & 96.25 & 95.03 & 91.23 \\
\hline
\end{tabular}

This result confirms that the actions of the yeast saccharase, amylase, proteinase, and catalase were promoted by visible monochromatic lights, which was found to be the stronger the greater the relative intensities of the absorbed rays under the same coloured lights.

The numerical values, namely the index-numbers divided by the relative intensities of the absorbed rays, that is, the proportions of the enzymic decomposition per unit intensity of each light are shown in the following Table.

Table X. Proportion of decomposition per unit intensity.

\begin{tabular}{|c|c|c|c|c|c|c|c|c|c|c|}
\hline \multicolumn{2}{|c|}{ Enzyme } & \multicolumn{3}{|c|}{ Saccharase } & \multicolumn{2}{|c|}{ Amylase } & \multicolumn{3}{|c|}{ Proteinase } & \multirow{2}{*}{$\begin{array}{c}\text { Catalase } \\
\text { minute } \\
15\end{array}$} \\
\hline \multicolumn{2}{|c|}{$\begin{array}{l}\text { I ength of time } \\
\text { acted upon }\end{array}$} & 30 & 60 & $\begin{array}{c}\text { minute } \\
120\end{array}$ & 6 & $\begin{array}{l}\text { hour } \\
12\end{array}$ & 24 & 48 & $\begin{array}{c}\text { hour } \\
72\end{array}$ & \\
\hline \multicolumn{2}{|c|}{ White } & 100.0 & $100.0^{\circ}$ & 100.0 & 100.0 & 100.0 & 100.0 & 100.0 & 100.0 & 100.0 \\
\hline \multirow[t]{4}{*}{ Red } & $a$ & 127.4 & 127.9 & 129.0 & 126.4 & 127.8 & 126.8 & 127.1 & 127.1 & - \\
\hline & $b$ & 147.6 & 148.4 & 149.6 & 153.9 & 156.6 & 145.8 & 1465 & 146.5 & 139.3 \\
\hline & $\mathrm{c}$ & 188.4 & 189.8 & 191.0 & 176.7 & 180.3 & 183.3 & 1850 & 185.0 & 168.0 \\
\hline & d & - & - & - & 206.6 & 214.1 & - & - & - & 199.9 \\
\hline \multicolumn{2}{|c|}{ Average } & 154.4 & 155.4 & 156.5 & 165.9 & 169.7 & 152.0 & 152.9 & 152.9 & 169.1 \\
\hline \multirow[t]{4}{*}{ Green } & $a$ & 155.1 & 156.1 & 156.4 & 127.0 & 123.3 & 154.0 & 154.8 & 154.8 & - \\
\hline & $\mathrm{b}$ & 185.3 & 186.8 & 187.7 & 148.4 & 162.4 & 184.0 & 185.7 & 185.7 & 143.8 \\
\hline & $\mathrm{c}$ & 274.3 & 278.7 & 279.2 & 188.7 & 192.7 & 261.2 & 267.7 & 267.7 & 173.2 \\
\hline & $d$ & - & - & - & 219.3 & 250.8 & - & - & - & 207.4 \\
\hline \multicolumn{2}{|c|}{ Average } & 204.9 & 207.2 & 207.8 & 170.9 & 182.3 & 199.7 & 202.7 & 203.2 & 174.8 \\
\hline \multirow[t]{3}{*}{ Blue } & $a$ & 182.0 & 183.5 & 184.3 & 126.4 & 125.3 & 175.6 & 177.3 & 177.6 & - \\
\hline & $b$ & 206.6 & 208.6 & 209.5 & 154.9 & 178.4 & 201.9 & 203.6 & 2040 & 163.3 \\
\hline & $\mathrm{c}$ & 383.4 & 392.1 & 390.9 & 212.1 & 219.4 & 356.1 & 3624 & 362.2 & 209.4 \\
\hline
\end{tabular}




\begin{tabular}{|c|c|c|c|c|c|c|c|c|c|c|}
\hline & $d$ & - & - & - & 272.1 & 281.7 & - & 一 & - & 264.9 \\
\hline \multicolumn{2}{|c|}{ Average } & 257.3 & 261.4 & 261.4 & 191.4 & 201.2 & 244.6 & 247.8 & 247.9 & 212.5 \\
\hline \multirow[t]{5}{*}{ Violet } & a & 185.4 & 186.8 & 187.8 & 132.3 & 129.1 & 180.4 & 181.9 & 182.3 & - \\
\hline & b & 233.0 & 235.5 & 236.5 & 169.8 & 194.8 & 225.3 & 227.6 & 227.7 & 202.8 \\
\hline & c & 470.8 & 481.6 & 480.3 & 238.3 & 245.2 & 437.1 & 445.9 & 444.9 & 235.1 \\
\hline & d & - & - & - & 334.2 & 375.4 & - & - & - & 324.3 \\
\hline & Average & 296.4 & 301.3 & 301.5 & 218.7 & 236.1 & 280.9 & 285.1 & 285.0 & 254.1 \\
\hline Biack & & - & - & 一 & - & - & - & - & - & - \\
\hline
\end{tabular}

According to these experiments, the extent of enzyme action per unit intensity by the same coloured light of saccharase, amylase, proteinase, and catalase was found to increase with reduction in the relative intensities of the absorbed rays, but the effect per unit intensity of the various coloured lights on the action of these enzymes was found to be approximately proportional to the wave number of the absorbed rays.

As to the cause of the inhibition of enzyme action due to the lights, GorbacH and LEACH (1930) from their studies on saccharase, attributed it to some hitch in the working of the tryptophane, the carrier of an active group in the enzyme. The former investigator and PICK (1932) later reported that inactivation of the enzyme with the aid of ultra-violet rays was greater in the presence of ozone, in contrast to its usual activation in the presence of molecular oxygen. LindNer $(1922 ; 1927)$ pointed out that this was more advantageous for fermentation owing to the vitamins formed in the yeast bodies through the action of the ultra-violet rays. According to GREEN (1897), in his work on amylase, the cause of increase in saccharification with the aid of rays, such as infra-red, red, orange, and blue, was the changes in some of the zymogen to an active enzyme.

The opinion of the writer is that the stable state $E$ of the enzyme molecules changes to the active state $E^{\prime}$ through radiant energy $(h \nu)$ possessing suitable vibration, when the action on the substrate $S$ becomes pronounced and changes $S$ to the labile state $S^{\prime}$, that is

$$
\begin{aligned}
& E+h \nu=E^{\prime} \\
& E^{\prime}+S=S^{\prime}
\end{aligned}
$$

He also believes that when the end product increases, it means that the action is promoted through the lights, it being clear that the promotion was found to be stronger, the greater the relative intensities of absorbed rays under the same coloured visible lights. If, however, the enzyme happens to meet with radiant energy possessing unsuitable vibration, it becomes to the destructive state $E^{\prime \prime}$, owing to photolysis, that is

$$
E+h \nu=E^{\prime \prime}
$$

and when the decomposition of the substrate is diminished it has an inhibiting effect on the action. 
Needless to say, if enzyme enter into special substrate, of which a portion of the molecules kept the state of the stable $E$ naturally, it can be changed to the active state $E^{\prime}$ at a certain temperature without radiant energy, and then changes a portion of $S$ by the action of $E^{\prime}$ to the labile state $S^{\prime}$. The change of $E$ to $E^{\prime}$ increases as a temperature rise to optimum; consequently it increases a possibility to change $S$ to $S^{\prime}$.

In case the enzyme received radiant energy possessing suitable vibration, $E^{\prime}$ is increased, and it changes $S$ plentifully to $S^{\prime}$. Thus, decomposition of subsrate advances more by the action of the enzyme receiving suitable radiant energy than by the opposite and it represents promotive effect.

If, however, the enzyme happens to meet with the radiant energy possessing a too great and unsuitable vibration, $E$ changes to $E^{\prime \prime}$, and the enzyme is destroyed. Thus, the action of enzyme on substrate becomes weaker than that which has not received radiant energy and it represents an inhibiting effect.

It is shown in such relation as

$$
E_{(m i n)}^{\prime \prime}>E^{\prime}>E
$$

$E_{(m i n)}^{\prime \prime}$ is the. state reached the acting limit, as seen in the case of radiant energy in the near ultra-violet region on saccharase, amylase and catalase. The region of wave length to reach $E^{\prime \prime}$ varies with the kinds of enzymes. It is seen that $E^{\prime}$ is plentifully formed, owing to the radiant energy in the near ultra-violet on proteinase and lipase, in spite of $E$ not changing to $E^{\prime \prime}$ except in the region of shorter wave length.

The increase of the promotive effect under the same coloured visible lights with increase in the relative intensities of the absorbedr ays, depends upon $E^{\prime}$ being abundantly formed along with the relative intensities, and also the effect per unit intensity of various coloured visible lights is due to $E^{\prime}$ being formed approximately proportional to wave number of the absorbed rays.

In conclusion, the writer wishes to express his thanks to Prof. U. SUzUki for his interest and encouragement, and also to the Imperical Academy for grants given in aid of this study. 